методичних посібників і рекомендацій.

Монографічне дослідження О. Лаврентьєвої загалом розвиває ідеї, погляди, наукові здобутки праць С. Гончаренка [1], В. Кременя [3], В. Кушніра [4], В. Краєвського [2] та інших щодо вдосконалення змісту професійної освіти, є значним науковим доробком в українській педагогічній науці, буде корисним викладачам природничих та інших дисциплін.

\title{
Література
}

1. Гончаренко С. Педагогічні дослідження: Методологічні поради молодим науковцям / Семен Устимович Гончаренко. - Київ - Вінниця : ДОВ «Вінниця», 2008. - 278 с. 2. Краевский В. Методология педагогики: новый етап : [учеб. пособие] / В. В. Краевский, Е. В. Бережнова. - Москва : Академия, 2006. - 400 с. 3. Кремень В. Освіта і наука в Україні інноваційні аспекти. Стратегія. Реалізація. Результати / Василь Григорович Кремень. - Київ : Грамота, 2005. - 448 с. 4. Кушнір В. Системний аналіз педагогічного процесу: методологічний аспект: [монографія] / Василь Андрійович Кушнір.- Кіровоград : Видавничий центр КДПУ, 2001. - 348 с.

УДК 378:[37.011.3-051:5]

Олена Лаврентьєва

\section{ФУНДАМЕНТАЛЬНА ПІДГОТОВКА ВЧИТЕЛЯ ПРИРОДНИЧИХ ДИСЦИПЛІН: СТАН, ПРОБЛЕМИ І ТЕНДЕНЦІЇ}

Лаврентьєва О. О. Фундаментальна підготовка вчителя природничих дисциплін: стан, проблеми і тенденції.

У статті розглядаються питання, існуючі підходи до формування змісту професійної підготовки вчителя природничих дисциплін на засадах фундаменталізації; наводяться результати дослідження стану професійної підготовки вчителя природничих дисциплін, виокремлюються проблеми і суперечності в досліджуваній науковій площині.

Ключові слова: професійна підготовка вчителя природничих дисциплін, фундаменталізація, компетентнісний підхід.

Лаврентьева Е. А. Фундаментальная подготовка учителя естественнонаучных дисциплин: состояние, проблемы и тенденции.

В статье рассматриваются вопросы, существующие подходы к формированию содержания профессиональной подготовки учителя естественнонаучных дисциплин на основе фундаментализации; приводятся результаты исследования состояния профессиональной подготовки, выделяются проблемы и противоречия в исследуемой научной плоскости.

Ключевые слова: профессиональная подготовка учителя естественнонаучных дисциплин, фундаментализация, компетентностный подход.

Lavrentieva O. O. Fundamental training of natural sciences teachers: state, problems and tendencies.

The issues, the existing approaches to the formation of the content for professional training process of future teachers in natural sciences on the basis of a fundamentalization are considered. The results of professional training research are given as well as the problems and contradictions in this scientific area are allocated.

Key words: professional training of teachers in natural sciences, fundamentalization, 
competence-based approach.

Зміна методологічної орієнтації освіти - 3 формування особистості на стратегію іiі розвитку й саморозвитку - вимагає від педагогічної теорії і практики розроблення нових моделей професійної підготовки, здійснюваної на засадах диференціації, диверсифікації, багаторівневості, фундаменталізації, комп'ютеризації, індивідуалізації, безперервності, гуманізації й гуманітаризації, які вважаються категоричними імперативами XXI ст. і які зазначені в основних документах, прийнятих у рамках Болонського процесу [1].

Професійну підготовку майбутнього вчителя розглядаємо як поліфункціональну відкриту систему, як самокероване, детерміноване, цілісне, системне, багатовимірне явище, що $\epsilon$ за своїм змістом комплексною програмою. Чинна на сучасному етапі система професійної підготовки майбутнього вчителя зорієнтована на формування в нього системи професійних знань, відповідних запитам практики й викликам глобалізації, інформатизації й полікультурності сучасного суспільства, а відтак - на формування світоглядної культури сучасного вчителя, професіоналізму в галузі професійно-педагогічної діяльності, його духовно-морального обличчя. Ці якості в сукупності забезпечують учителеві високий авторитет, конкурентоспроможність, ефективність, відповідність вимогам практики, відкритість інноваціям і перспективам у майбутній професійній діяльності (В. Бондар, Є. Бондаревська, С. Гончаренко, Н. Гузій, В. Кузь, Н. Кузьміна, 3. Курлянд, В. Луговий, О. Мороз, Л. Пуховська, В. Радул, С. Сисоєва, Л. Хомич, В. Шахов, Н. Якса).

Разом із тим, уже сьогодні дослідники, зокрема І. Зязюн, В. Кремень, Н. Ничкало, В. Орлов, В. Сєріков, В. Сластьонін та інші, вказують на слабкі місця професійної підготовки вчителя, для нейтралізації яких необхідно забезпечити реальну підготовку: педагогадослідника, педагога, який вільно володіє іноземною мовою й комп'ютерними технологіями; педагога-психолога; педагога, спроможного по-новому організувати навчальний процес, підготувати в достатньому обсязі не лише творців інтелектуальних ресурсів, але й інноваційних особистостей; педагога-майстра, який має широке коло однодумців, помічників, послідовників [2, с. 22].

Метою статті є огляд існуючих підходів до формування змісту професійної підготовки вчителя природничих дисциплін на засадах фундаменталізації.

Фундаменталізація вищої педагогічної освіти передбачає перегляд аксіологічних орієнтирів і пріоритетів з примата прагматичних і вузькоспеціалізованих знань на розвиток загальної культури й наукових форм мислення. Основою фундаменталізації є методологічно важливі, первинні, стрижневі, системотвірні та інваріантні знання, що відповідають цілісному світосприйняттю й мисленню особистості та ï адаптації в мінливих соціальноекономічних і технологічних умовах. Як інструмент залучення до сучасної інтелектуальної культури, фундаментальна освіта покликана сприяти досягненню якісно нового рівня компетентності, що виявляється плідним не тільки для розв'язання проблем локальної галузі діяльності, але й для всієї сфери професійної праці [3, с. 138].

Аналіз наявних підходів до системи професійної підготовки майбутнього вчителя природничих дисциплін показав суттєві розбіжності в поглядах стосовно фундаменталізації. Одні дослідники розуміють фундаменталізацію як поглиблену підготовку, тобто «освіту вглиб», інші - як різнобічну гуманітарну й природничо-наукову освіту на основі оволодіння фундаментальними знаннями - «освіта вшир». Проте, до групи фундаментальних наук належать ті, чиї основні визначення, поняття й закони первинні, не є наслідком інших наук, безпосередньо відбивають, синтезують у закони й закономірності факти, явища природи й 
суспільства [5]. Загалом процес фундаменталізації, наголошує О. Романовський, $\epsilon$ збільшенням обсягу та ролі дисциплін загальнонаукового циклу (не тільки логікоматематичних і природничо-наукових знань, але й соціально-психологічних, філософських, культурно-історичних, а також суспільно-політичних); посилення зв'язків між дисциплінами навчального плану; перебудову циклу професійних дисциплін із посиленою увагою до світоглядних i соціальних проблем; забезпечення формування у процесі освіти методологічної культури фахівця; вивчення спеціальних дисциплін, спрямованих на формування навичок володіння засобами й технологією інформаційної культури тощо [3, c. 134].

Водночас побутує думка про те, що вчителі повинні бути, передусім, високоосвіченими людьми із грунтовною освітою в математичній та природничій галузі, однак, на іншу думку, більш важливим $є$ методичний складник, що сприяє ефективній організації викладання й учіння, сприяє покращенню стану вчителя й успіхам учня. Є також прибічники освітньої програми, що задовольнила б обидві сторони. Існує й четверта позиція, яка розглядає фундаменталізацію лише в аспекті галузевої науки й не розповсюджує цю вимогу на інші, зокрема гуманітарні дисципліни. Проте, фундаменталізацією є така методологія формування змісту освітнього процесу, яка припускає гармонійне поєднання загальноосвітніх і спеціальних знань, моральних, естетичних і соціальних цінностей, забезпечує можливості повноцінного розуміння теоретичних підстав професійної й соціальної діяльності, що розвиває здатність до цілісного мислення, охоплює взаємозв'язки окремих галузей знань, створює передумови для наступного життєвого й професійного самовизначення особистості [5]. Отже, сучасними механізмами фундаменталізації професійної підготовки майбутніх учителів $є$ розробка та внесення фундаментальних навчальних курсів із фахових, філософських, психолого-педагогічних дисциплін.

Отже, якщо в минулому дискусії точилися навколо двох пріоритетів професійної підготовки вчителя: предметно-орієнтована чи педагогічно-орієнтована освіта, то сьогодення характеризується розумінням необхідності гуманітарних, культурологічних та інших концепцій, які б об’єднали наявні погляди.

Основи як професійної, так і загальної культури закладаються у процесі всебічної підготовки фахівця. Така система повинна охоплювати: фундаментальну методологічну i світоглядну підготовку; широку гуманітарну підготовку; теоретичну й практичну підготовку 3 профілюючих дисциплін; творчу підготовку за фахом; підготовку в галузі науководослідної й дослідницької роботи, формування навичок самостійної творчої діяльності. Зазначені головні напрями підготовки розгалужуються на низку взаємозалежних, більш часткових за змістом і формами, однак, за обсягом і змістом зорієнтовані на майбутню професію й спеціальність. У системі професійної підготовки як один зі складників виокремлюється й фундаментальна підготовка, що передбачає вивчення теоретичних основ i підвалин загальнофілософських, загальнокультурних, психолого-педагогічних i спеціальних знань відповідно до новітніх досягнень науки [3]. Стрижнем такої підготовки є методологічна підготовка, що передбачає для майбутнього вчителя природничих дисциплін вивчення не лише загальнонаукової, природничо-наукової методології і методології педагогіки й психології, а ще й методологічних засад творчої, дослідницької діяльності, пізнання й самопізнання.

Із метою вивчення специфіки і тенденцій, впливових чинників сучасної професійної підготовки вчителя природничих дисциплін нами було проведено спеціальне дослідження. До нього було залучено 57 учителів природничих дисциплін м. Кривого Рогу, 30 викладачів 
фахових кафедр і 245 студентів природничих спеціальностей КПІ ДВНЗ «КНУ».

Розгляд чинних навчальних планів КПІ ДВНЗ «КНУ» відобразив наявність самостійних, але досить вагомих складників, що перекривають один одного і в єдності реалізовують поставлені перед вищою педагогічною школою провідні завдання. Було виявлено, що обсяг предметів циклу природничо-наукової підготовки для майбутніх учителів природничих дисциплін $є$ значним і має на меті грунтовне ознайомлення з сучасною природничо-науковою картиною світу; формування знань, які адекватно відображають об’єктивний світ. Провідними принципами постають фундаменталізація й генералізащія сучасних природничо-наукових знань, що відображає, зокрема, діалектику емпіричного й теоретичного у структурі знань, їх концентрування навколо провідних теорій; сприяє формуванню світогляду та наукового стилю мислення студентів. Ці тенденції також зумовлюють внесення до навчальних планів інтегрованих курсів, як-от: екологія, біоніка, біофізика, біогеографія, біохімія, екохімія тощо.

Порівняння питомої ваги дисциплін професійної науково-предметної підготовки (2528,1 \%), психолого-педагогічної підготовки (7,5%), обсягу практичної підготовки (від 5,4 \% на фізико-математичному, 9,5 \% на природничому до 10,8 \% на географічному факультетах, включаючи суто педагогічну практику лише в 3,7 \% на кожному), методичної підготовки (у середньому $5 \%$ ) відображає урахування вимог компетентнісного підходу й нове бачення структури професійної підготовки вчителя природничих дисциплін, проте переважно в галузі предмета викладання.

Більш детальне вивчення навчальних програм вказує на недостатню фундаментальну домінанту у блоці психолого-педагогічних дисциплін. Наприклад, для спеціальностей 6.040203 Фізика, 6.040101 Хімія та 6.040104 Географія у варіативній частині циклу професійної науково-предметної підготовки, що встановлює університет - жодної психолого-педагогічної, а 3 тих, які обирає студент- у співвідношенні 1:3 на користь базового предмета викладання.

Ефективність професійної підготовки визначається також змістовим наповненням дисциплін. Аналіз анкетування виявив, що загалом задоволені сучасною системою професійної підготовки: 82,4 \% 3 опитаних нами вчителів, 60 \% викладачів, 55 \% студентів 1-го курсу, $75 \%$ студентів 4-го і 80 \% студентів 5-го курсів. Не мають визначеної думки з цього питання: 5,2 \% вчителів, $20 \%$ викладачів і 8,1\% студентів. Різко негативно оцінюють існуючу систему професійної підготовки загалом 12,4\% вчителів, переважно зі стажем до 10 років, і $10 \%$ викладачів. Наводять такі аргументи: погана і морально застаріла матеріально-технічна база, що особливо показово для вивчення природничих дисциплін; недостатній рівень комп'ютеризації та ступеня впровадження IKT, не відповідний сфері викладання професійний рівень професорсько-викладацького складу; дезбалансованість змісту професійної підготовки на користь загальноосвітніх дисциплін за рахунок фахових; відсутність концептуальної ідеї в підготовці вчителя природничих дисциплін, що перетворює сучасну систему на конгломерат дисциплін, курсів та спецкурсів і позбавляє стрижневої спрямованості на визначену модель учителя. Ставлення студентів, викладачів і вчителів до змісту професійної підготовки узагальнено в табл. 1. 
Ступінь важливості складників професійної підготовки

за результатами опитування

\begin{tabular}{|l|c|c|c|c|}
\hline \multirow{2}{*}{$\begin{array}{c}\text { Складники професійної } \\
\text { підготовки }\end{array}$} & \multicolumn{4}{c|}{ Ранг вибору } \\
\cline { 2 - 5 } & Учителі & Викладачі & $\begin{array}{c}\text { Студенти } \\
\text { 4-го курсу }\end{array}$ & $\begin{array}{c}\text { Студенти } \\
\text { 5-го курсу }\end{array}$ \\
\hline загальнотеоретичний з предмета & 1,3 & 1,1 & 1,0 & 1,0 \\
\hline психологічний & 4,3 & 4,8 & 4,0 & 3,5 \\
\hline педагогічний & 2,6 & 3,5 & 4,0 & 3,0 \\
\hline методичний & 3,3 & 3,3 & 3,0 & 2,5 \\
\hline культурологічний & 5,7 & 5,1 & 6,5 & 7,0 \\
\hline практичний & 3,6 & 3,1 & 3,0 & 3,2 \\
\hline у галузі ІКТ & 5,0 & 1,5 & 1,3 & 1,5 \\
\hline
\end{tabular}

Як бачимо, спостерігається значне розходження між відповідями вчителів, з одного боку, та викладачами й студентами - 3 іншого. Із цього можна зробити кілька висновків: 1) ані викладачі, ані студенти не досить чітко уявляють реалії педагогічної професії; 2) більшість респондентів є прихильниками функціонального підходу, тобто вважають, що професійна підготовка має вичерпуватися лише підготовкою майбутнього вчителя до виконання типових функцій (навчальних, виховних, методичних тощо). Із табл. 1 видно, що найвищий ранг має спеціальна теоретична підготовка 3 предмета викладання, за нею педагогічна, методична та практична підготовки.

Узагальнені відповіді респондентів на запитання «Виходячи з уявної ситуації «Якби міністром був я...», на якій провідній ідеї вищої педагогічної освіти Ви б зробили наголос $\mathrm{i}$ чому?» ми розмістили в табл. 2.

Таблиия 2

Ступінь підтримки респондентами провідних концептуальних засад формування змісту професійної підготовки вчителя

\begin{tabular}{|l|c|c|c|c|}
\hline \multirow{2}{*}{$\begin{array}{c}\text { Провідні ідеї вищої } \\
\text { педагогічної освіти }\end{array}$} & \multicolumn{4}{|c|}{ \% опитаних } \\
\cline { 2 - 5 } & Учителі & Викладачі & $\begin{array}{c}\text { Студенти } \\
\text { 4-го курсу }\end{array}$ & $\begin{array}{c}\text { Студенти } \\
\text { 5-го курсу }\end{array}$ \\
\hline Компетентнісний підхід & 78,9 & 50,0 & 70,0 & 72,0 \\
\hline Фундаменталізація & 15,7 & 33,4 & 24,0 & 20,0 \\
\hline Культурологічний підхід & 5,4 & 16,6 & 6,0 & 8,0 \\
\hline
\end{tabular}

Як видно 3 даних табл. 2, результати дещо розходяться 3 попередніми стосовно складників професійної підготовки, адже компетентнісні аспекти - психолого-педагогічна, методична та практична підготовки не отримали рангової оцінки вище «3». На наш погляд, це можна інтерпретувати як «ефект луни», коли ті чи ті «модні» тенденції не осмислюються й некритично переносяться на практику (О. Орлов). Уточнюючі бесіди показали, що переважна більшість респондентів не може схарактеризувати сутність понять «фундаменталізація», «компетентнісний підхід», «культурологічний підхід». Фундаменталізація вбачається лише в контексті предмета викладання, або як антипод до психолого-педагогічної й соціально-гуманітарної підготовки.

Особливий інтерес складає оцінка студентами рівня отриманих ними природничонаукових знань і практичних навичок. Від 1-го до 5-го курсу зростає кількість критичних оцінок щодо їх достатності. Так, якщо на 1-му курсі частка тих, хто дає найбільш критичні оцінки становить, 8 \%, на 2-му - $20 \%$, на 4-му - 25,2 \%, а на 5-му - 27,8 \%. За параметрами 
«фундаментальність», «системність» і «сучасність» одержуваних знань, з-поміж випускників бакалаврату кожен третій не задоволений рівнем запропонованих знань із природничонаукових предметів, кожен другий - iз міждисциплінарних курсів, 44,3 \% - дисциплін психолого-педагогічного циклу, 17,3\% - змістом курсів із методик викладання, 69,5\%дисциплін соціально-гуманітарного циклу, 27,8 \% - дисциплін додаткової спеціальності («інформатика» чи для біологів - «практична психологія»), покращення змісту практичної підготовки в цьому напрямі очікують 60 \% майбутніх учителів. Окрім вікової динаміки, не менш цікаві дані пов'язані зі ставленням студентів до змісту професійної підготовки залежно від їхньої академічної успішності. Установлено, що чим нижче успішність студента, тим менш він критичний щодо якості одержуваної професійної освіти.

Нами виявлено також висхідну динаміку загальнокультурного розвитку студентів, що досягає на заключних етапах прийнятних значень. Проте, для переважної більшості майбутніх учителів процес становлення професійно-педагогічної культури не стає провідним чинником їх професійної підготовки.

Отже, нині можна вважати концептуально завершеним образ професійної підготовки майбутнього вчителя, що визначає особливого роду навчально-виховне середовище вищої педагогічної школи. Водночас інтеграція, що підсилюється в галузі технологічного, природничо-наукового й гуманітарного знання як провідна тенденція розвитку сучасної науки, усе більше позначається на завданнях професійної підготовки.

Нині, зазначає А. Тряпіцина, реалізуються, принаймні, дві моделі професійної підготовки майбутнього вчителя: адаптаційна, спрямована на адаптацію фахівця до умов майбутньої роботи та модель професійного розвитку й саморозвитку. На жаль, друга модель часто лише декларується, а функціонує, як і раніше, модель адаптаційна [4].

До відносно сильних сторін сучасної системи професійної підготовки варто віднести достатній рівень умотивованості й технологічної готовності студентів до майбутньої професійної діяльності в дидактичному, методичному й виховному їі аспектах, при досить невисоких, на жаль, показниках розвитку когнітивності, рефлексивності і творчої спрямованості майбутніх учителів. Опитані нами студенти природничих факультетів достатньо високо оцінили рівень і якість природничо-наукової освіти; реальність отримання другої вищої непедагогічної освіти й додаткової спеціалізації. Водночас висловили зауваження щодо поганої й морально застарілої матеріально-технічної бази для засвоєння природничих дисциплін; недостатній рівень комп'ютеризації та ступеня впровадження IКТ, дезбалансованість змісту професійної підготовки на користь загальноосвітніх дисциплін за рахунок фахових; виявили незадоволеність якістю одержуваних знань за параметрами «фундаментальність», «системність» і «сучасність» для майже всіх напрямів професійної підготовки.

Отже, у результаті нами виявлено три рівні суперечності в досліджуваній наукові площині, а саме: на рівнях концептуалізації й організації процесу професійної підготовки вчителів та на рівні особистісного професійного становлення майбутнього вчителя природничих дисциплін. Провідною вважаємо суперечність між необхідністю приведення сучасної системи професійної підготовки відповідно до ознак постіндустріальної культури й пануванням раціональної парадигми, що вичерпала свою культурну адекватність у сучасній соціокультурній ситуації.

\section{Література}

1. Аносов І. П. Сучасний освітній процес: антропологічний аспект : [монографія] / Іван Павлович Аносов. - Київ : Твім інтер, 2003. - 391 с. 2. Зязюн І. Немає педагогіки без 
педагога / Іван Зязюн // Рідна школа. - 2012. - № 4-5 (квітень-травень). - С. 19-23. 3. Романовський О. Г. Професійна підготовка майбутнього фахівця у контексті фундаменталізації сучасної освіти / О. Г. Романовський // Професійна освіта і ціннісні орієнтири сучасності : [зб. наук. праць].- Київ ; Харків : НТУ ХПГ, 2009. - С. 132-138. 4. Тряпицына А. П. Актуальные проблемы обновления современной системы образования / А. П. Тряпицына // Академический вестник Института педагогического образования и образования взрослых РАО. - 2012. - № 3. - С. 4-10. 5. Харченко Л. Н. Теория и практика биологического образования в современном педагогическом вузе : дисс. ... д-ра пед. наук : 13.00.08 / Харченко Леонид Николаевич. - Ставрополь, 2002. - 399 с.

УДК 37.013 .32

Геннадій Лещенко

\section{ДИДАКТИЧНЕ ЗАБЕЗПЕЧЕННЯ ПРОФЕСІЙНОЇ НАДІЙНОСТІ МАЙБУТНІХ ФАХІВЦІВ 3 АВАРІЙНОГО ОБСЛУГОВУВАННЯ ТА БЕЗПЕКИ НА АВІАЦІЙНОМУ ТРАНСПОРТI}

Лещенко Г. А. Дидактичне забезпечення професійної надійності майбутніх фахівців 3 аварійного обслуговування та безпеки на авіаційному транспорті.

У статті на основі огляду навчальних планів і програм аналізується дидактичний компонент фахової підготовки майбутніх фахівців з аварійного обслуговування та безпеки на авіаційному транспорті. Стверджується, що лише знань, умінь і навичок, отриманих у навчальному закладі, недостатньо для забезпечення професійної надійності майбутніх фахівців. Установлено, що існуючі підходи, технології професійної підготовки в освітньому закладі не забезпечують повною мірою формування професійної надійності майбутніх фахівців з аварійного обслуговування та безпеки на авіаційному транспорті.

Ключові слова: професійна надійність, навчальна дисципліна, професійне становлення, професійно важливі психофізіологічні якості, аварійно-рятувальні роботи, повітряне судно.

Лещенко Г. А. Дидактическое обеспечение профессиональной надежности будущих специалистов по аварийному обслуживанию и безопасности на авиационном транспорте.

В статье на основе обзора учебных планов и программ анализируется дидактический компонент профессиональной подготовки будущих специалистов по аварийному обслуживанию и безопасности на авиационном транспорте. Утверждается, что только знаний, умений и навыков, полученных в учебном заведении, недостаточно для обеспечения профессиональной надежности будущих специалистов. Установлено, что существующие подходы, технологии профессиональной подготовки в образовательном учреждении не обеспечивают в полной мере формирования профессиональной надежности будущих специалистов по аварийному обслуживанию и безопасности на авиационном транспорте.

Ключевые слова: профессиональная надежность, учебная дисциплина, профессиональное становление, профессионально важные психофизиологические качества, аварийно-спасательные работы, воздушное судно.

Leshchenko G. A. The didactic maintenance of professional reliability of future specialists in aviation emergency service and safety.

The didactic component for professional training of future specialists in aviation emergency 